\title{
Hubungan Produksi Susu Berdasarkan Grade MPPA dengan Performa Reproduksi
}

\author{
The Effect of Milk Production Based on MPPA Grade with Reproductive Performance
}

\author{
I.Komala ${ }^{1}$, I.Arifiantini ${ }^{2}$, C.Sumantri ${ }^{1}$, L.I.T.A Tumbelaka ${ }^{2}$ \\ ${ }^{1}$ Departemen Ilmu Produksi dan Teknologi Peternakan, Fakultas Peternakan, Institut Pertanian Bogor \\ Jln. Agatis Kampus IPB Dramaga Bogor \\ ${ }^{2}$ Departemen Klinik, Reproduksi dan Patologi, Fakultas Kedokteran Hewan IPB, Institut Pertanian Bogor \\ Jln. Agatis Kampus IPB Dramaga Bogor \\ Correspondence author : iyepk@yahoo.com
}

\begin{abstract}
The aim of this study was to determine the potential effect of milk production based on Most Probability Producing Ability (MPPA) on reproductive performance. The secondary data of body condition score (BCS), reproductive traits and milk production were collected from Baturraden Breeding Center. Identification of FSH sub unit beta Gene polymorphisms were conducted by polymerase chain reaction and restriction fragment length polymorphism (PCR-RFLP) method. Milk production data was analyzed with formula repeatability (r), heritability (h) and Most Probable Producing Ability (MPPA). The data were also analyzed using correlation and ANOVA (GLM). The results showed that repeatability and heritability of milk production values were 0,84 and 0,4 . Gen FSH sub-unit beta was monomorphic fixed to $\mathrm{AB}$ genotype and had no effect on the ability of milk production and reproductive performance. BCS values had been affected significantly on milk production based on grade of MPPA. The correlation analysis showed that the BCS had a sizable effect on milk production with a value of $r=0,68$. The relationship between BCS with milk production was expressed in the regression equation MPPA $(\mathrm{Kg})=-59+1991 \mathrm{BCS}$, means the rise of unit will increase milk production of $1991 \mathrm{~kg} /$ lactation.
\end{abstract}

\section{PENDAHULUAN}

\section{Latar Belakang}

Populasi sapi perah pada tahun 2011 di Indonesia menurut Direktorat Jendral Peternakan dan Kesehatan Hewan (2012) tercatat sebanyak 597.129 ekor dengan laju pertumbuhan populasi mencapai $4,32 \%$ per tahun. Secara geografis penyebaran sapi perah tidak merata di seluruh tanah air, sekitar $97 \%$ dari populasi terkonsentrasi di Pulau Jawa (Direktorat Budidaya Ternak 2012) dengan rataan produksi susu sekitar 10,5 liter/ekor/hari. Populasi dan produktivitas sapi perah tersebut tidak sebanding dengan tingkat konsumsi susu penduduk Indonesia yang berjumlah 210 juta jiwa. Kebutuhan akan susu dalam negeri diproyeksikan akan meningkat selaras dengan pertambahan penduduk dan tingkat kesadaran gizi masyarakat.

Populasi sapi perah nasional yang rendah saat ini menyebabkan produksi susu lokal hanya menyuplai sekitar 20\% dari konsumsi susu nasional dan apabila keadaan produksi susu nasional dibiarkan terus tanpa ada upaya untuk meningkatkan populasi dan produktivitas sapi perah tersebut, maka ketersediaan susu untuk memenuhi kebutuhan penduduk Indonesia semakin kurang, sehingga ketergantungan susu impor semakin besar.

Upaya yang harus dilakukan untuk meningkatkan produksi susu adalah dengan meningkatkan produktivitas dan kapasitas reproduksi sapi perah betina yang ada di Indonesia, antara lain melalui perbaikan mutu genetik, seleksi terhadap sifat produksi dan reproduksi. Reproduksi dan produksi susu sapi perah merupakan sifat yang dikendalikan oleh banyak gen (kuantitatif), sehingga ekspresi tersebut merupakan akumulasi dari pengaruh genetik, lingkungan dan interaksi kedua faktor tersebut. Faktor genetik merupakan hal yang lebih penting dan memperoleh perhatian pada program pemuliaan ternak karena unsur ini akan diwariskan tetua kepada keturunannya (Falconer \& Mackay 1996).

Performa reproduksi betina menurut Hidayat et al. (2002) dapat dievaluasi berdasarkan beberapa indikator reproduksi seperti: (1) umur sapi dara saat berahi, kawin, bunting dan beranak pertama, (2) jarak waktu saat beranak sampai ke kawin (IB) pertama (service days), (3) jarak waktu saat beranak sampai terjadi kebuntingan (days open), (4) angka konsepsi (CR), (5) jumlah kawin (IB) untuk mencapai satu kebuntingan (S/C), (6) jarak antara kelahiran (calving Interval) dan (7) angka abortus, angka infertilitas dan angka gangguan reproduksi. Indikator reproduksi yang berhubungan langsung dengan produksi susu adalah jarak antara kelahiran dan jarak waktu saat beranak sampai terjadi kebuntingan.

Produktivitas sapi perah betina dapat dievaluasi dengan mengkaji parameter-parameter genetik yang digunakan sebagai indikator produktivitas ternak tersebut. Salah satu indikator yang digunakan untuk mengevaluasi kemampuan produksi susu adalah Most Probable Producing Ability (MPPA). Indonesia memiliki beberapa Balai Pembibitan Ternak Unggul (BPTU), diantaranya adalah Balai Besar Pembibitan Ternak Unggul (BBPTU) sapi perah Baturaden yang menjadi acuan peternak di Indonesia untuk mendapatkan ternak perah unggul. Seleksi yang sudah dilakukan terhadap sapi perah adalah uji zuriat (progeny 
testing) dan uji performance. Uji zuriat ini memerlukan waktu yang lama dan biaya tinggi, sedangkan uji performance tingkat akurasi masih rendah, karena penampilan sapi unggul secara fenotip tidak menjamin bahwa sapi tersebut unggul dalam hal reproduksi. Pemanfaatan teknologi biologi molekuler sebagai penanda seleksi akan sangat membantu dalam proses seleksi, karena prosesnya cepat, biaya yang lebih murah dengan tingkat keakuratan tinggi.

Penelitian tentang biologi molekuler pada ternak betina telah dilakukan oleh Liu et al. (2009), menggunakan gen FSH sub-unit beta, gen tersebut terdiri dari tiga exon yang terdapat pada sapi dan babi. Xiaopeng et al. (2010) melaporkan bahwa litter size atau jumlah anak sekelahiran pada domba sangat dipengaruhi oleh keragaman gen FSH sub-unit beta. Di Indonesia penelitian mengenai seleksi pada ternak jantan telah dilakukan oleh Ishak et al. (2012) menggunakan gen FSH sub-unit beta terhadap kualitas sperma, dan diketahui terdapat keragaman atau polimorfik gen FSH sub-unit beta pada sperma sapi FH, Brahman, Simmental dan Limousin. Genotipe AB mempunyai persentase abnormalitas sperma lebih kecil dibandingkan dengan genotipe $\mathrm{BB}$ dan $\mathrm{AA}$.

Pemanfaatan teknik biologi molekuler dan seleksi betina perlu dilakukan, oleh karena itu dalam penelitian ini dikaji pengaruh gen FSH sub-unit beta terhadap performa reproduksi dan potensi produksi susu, serta pengaruh performa reproduksi terhadap kemampuan produksi susu sapi FH.

\section{METODOLOGI PENELITIAN}

\section{Waktu dan Lokasi Penelitian}

Penelitian dilakukan pada bulan September 2012 sampai dengan Juli 2013 di BBPTU Baturaden Jawa Tengah dan Laboratorium Genetika Molekuler Departemen Ilmu Produksi dan Teknologi Peternakan, Fakultas Peternakan IPB.

\section{Metode Penelitian}

Penelitian ini dibagi menjadi dua tahap yaitu: tahap pertama berupa koleksi data sekunder seperti body condition score (BCS), data reproduksi dan produksi susu

1. Data body condition score (BCS) dari 187 ekor sapi FH laktasi selama 5 laktasi.

2. Data reproduksi yaitu interval kawin pertama setelah beranak, masa kosong (days open), lama kebuntingan, selang bearanak (calving interval), Service perconception (S/C) dan Conseption Rate (CR) dari 187 ekor sapi FH laktasi selama 5 laktasi.

3. Data produksi susu, yaitu data produksi susu harian dari 213 ekor FH laktasi selama 5 laktasi.

Penelitian Tahap II analisis molekuler gen FSH sub unit beta dihubungkan dengan sifat fenotipik yang diukur seperti BCS, reproduksi dan produksi susu.

\section{Koleksi Sampel Darah}

Sampel darah sebanyak $5 \mathrm{ml}$ diambil dari 187 ekor sapi FH betina laktasi melalui vena jungularis dengan venojet tanpa heparin. Sampel ditambah etanol absolut $1: 1$, dan disimpan pada suhu ruang. Untuk kemudian dilanjutkan ekstraksi DNA

\section{Ekstraksi DNA}

Ekstraksi DNA dari sampel darah menggunakan metode phenol-chloroform (Sambrook et al. 1998) yang dimodifikasi oleh Andreas et al. (2010) sampel darah yang dimasukkan dalam alkohol.

\section{Amplifikasi Ruas Gen FSH Sub Unit Beta}

Amplifikasi kedua gen ini dilakukan menggunakan metode PCR (polymerase chain reaction). Pereaksi yang digunakan untuk kedua gen target adalah $2 \mu \mathrm{l}$ sampel DNA, $0.1 \mu \mathrm{l}$ primer (10 pmol), $0.1 \mu \mathrm{l}$ dNTPs (200 $\mu \mathrm{M}), 0.25 \mathrm{MgCl}_{2}(1 \mathrm{mM})$, dan 0.1 unit dreamTaq ${ }^{\mathrm{TM}}$ DNA polymerase $\left(\right.$ Fermentas $\left.^{\circledR}\right)$. Amplifikasi in vitro dengan mesin thermal cycler dilakukan pada suhu denaturasi awal $95^{\circ} \mathrm{C}$ selama 5 menit, 35 siklus yang terdiri dari denaturasi $95^{\circ} \mathrm{C}$ selama 45 detik, annealing $63^{\circ} \mathrm{C}$ (FSH sub-unit beta) selama 45 detik, ekstensi $72^{\circ} \mathrm{C}$ selama 1 menit dan ekstensi akhir $72^{\circ} \mathrm{C}$ selama 5 menit. Sekuens primer yang digunakan dapat dilihat pada Tabel 1.

\section{Penentuan Genotipe dengan Pendekatan PCR-RFLP Genotipe dilakukan dengan pendekatan} Restriction Fragment Length Polymorphism yang divisualisasikan pada gel agarose $2 \%$ dengan buffer 0,5 TBE (tris borat EDTA) ditambah ethidium bromida (EtBr), diaplikasikan pada tegangan 100 Volt selama 40 menit. Hasil visualisasi menggunakan UV transluminator dan difoto menggunakan gel documentation system (Alpha imager $^{\circledR}$ ). Enzim restriksi yang digunakan pada gen FSH sub-unit beta adalah Pst1

\section{Analisis Data \\ 1. Analisis Data Produksi Susu \\ Produksi susu perlaktasi dari masing-masing individu kemudian distandardisasi menggunakan faktor koreksi lama laktasi 305 hari dan umur dewasa induk berdasarkan Dairy Herd Improvement Association- United States Departement of Agriculture (DHIA-USDA). Setelah data produksi susu terstandardisasi, nilai ripitabilitas dan MPPA dihitung. Nilai pendugaan MPPA sapi betina yang telah didapat kemudian diurutkan berdasarkan peringkat nilai MPPA tersebut.}

\section{A. Ripitabilitas (r) \\ Perhitungan ripitabilitas produksi susu menggunakan metode sidik ragam satu arah dengan jumlah}

Tabel 1 Sekuens primer yang digunakan.

\begin{tabular}{lll}
\hline Primer & Sequence & Suhu Annealing \\
\hline FSH sub-unit beta & F : 5 'CTTCCAGACTACTGTAACTCATC‘3 & 63oC \\
& $\mathrm{R}:$ 5'GTAGGCAGTCAAAGCATCCG‘3 & \\
\hline
\end{tabular}

Ket : An = suhu annealing (Dai et al. 2009) 


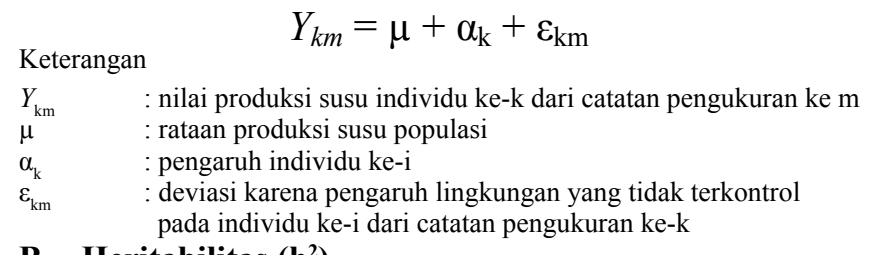

\section{B. Heritabilitas $\left(\mathbf{h}^{2}\right)$}

Pendugaan nilai heritabilitas dihitung berdasarkan metode korelasi saudara tiri (paternal halfsib correlation) dengan jumlah anak per pejantan yang tidak sama (unbalance design) menurut Becker (1975). Model statistiknya adalah sebagai berikut:

$$
\begin{array}{ll}
\qquad Y_{i k}=\mu+\alpha_{\mathrm{i}}+\varepsilon_{\mathrm{ik}} \\
\text { Keterangan } \\
Y_{\mathrm{ik}} & : \text { nilai produksi susu individu (anak) ke-k dari pejantan ke -i } \\
\mu & : \text { rataan produksi susu populasi } \\
\alpha_{\mathrm{i}} & \text { : pengaruh pejantan ke-i } \\
\varepsilon_{\mathrm{ik}} & \text { : deviasi karena pengaruh lingkungan yang tidak terkontrol } \\
& \text { pada individu (anak) ke-i dari pejantan ke-k }
\end{array}
$$

\section{Pendugaan Nilai Most Probability Producing Ability (MPPA)}

Perhitungan MPPA dapat dilakukan berdasarkan pendekatan Warwick (1983) dengan rumus:

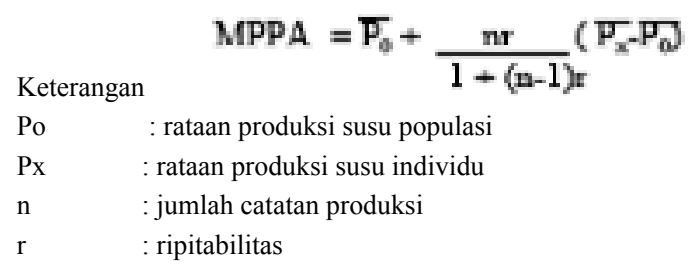

\section{HASIL DAN PEMBAHASAN}

Amplifikasi Ruas Gen FSH sub-unit beta

Panjang produk amplifikasi ruas gen FSH sub-unit beta sebagian intron 2 dan bagian penuh ekson 3 adalah 313 bp disajikan pada Gambar 1 .

Produk PCR gen FSH sub-unit beta yang telah dipotong menggunakan enzim restriksi Pst 1 menghasilkan 1 macam genotype, yaitu AB. Hasil RFLP dengan pemotongan produk PCR dengan enzim Pstl menunjukkan bahwa dari $100 \%$ tidak ada variasi atau monomorfik (genotipe AB). Hal tersebut dimungkinkan karena sapi-sapi tersebut di impor dari tempat yang sama dan sudah terseleksi.

\section{Parameter Genetik Produksi Susu}

Parameter genetik yang diamati adalah heritabilitas $\left(\mathrm{h}^{2}\right)$ dan ripitabilitas (r). Heritabilitas didasarkan pada metode korelasi saudara tiri sebapak (paternal halfsib correlation), sedangkan ripitabilitas dihitung berdasarkan analisis sidik

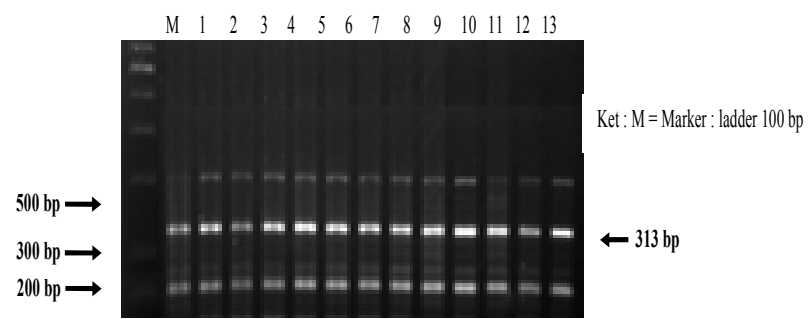

Gambar 1 Visualisasi hasil amplifikasi ruas gen FSH sub-unit beta ragam klasifikasi satu arah. Kedua parameter genetik ini selanjutnya digunakan untuk menentukan nilai MPPA dan PBV dari masing-masing ternak. Nilai laheritabilitas yang didapat yaitu 0,4 dan dan ripitabilitasnya 0,84 .

\section{Ripitabilitas}

Nilai ripitabilitas produksi susu di BBPTU-SP Baturraden tergolong tinggi yaitu 0,84, sesuai dengan pernyataan Pallawaruka (1999) yaitu ripitabilitas tergolong ke dalam kategori tinggi jika nilainya lebih besar dari 0,4 . Nilai tersebut menunjukkan bahwa adanya hubungan genetik yang tinggi antara produksi susu pertama dengan produksi susu berikutnya, pada setiap individu.

\section{Heritabilitas}

Nilai heritabilitas 0,4 nilai ini tergolong sedang sesuai dengan pernyataan Noor (2010) serta Warwick dan Legates (1979) bahwa nilai heritabilitas kisaran 0,20,4 tergolong sedang. Nilai tersebut menunjukkan bahwa pewarisan sifat produksi susu pada keturunannya tergolong sedang.

\section{Pendugaan Nilai MPPA}

Kemampuan produksi individu sapi dapat diketahui dengan metode MPPA. Daya produksi susu yang diketahui dari perhitungan MPPA merupakan pendugaan produksi susu pada laktasi berikutnya. Ternak yang memiliki daya produksi yang tinggi akan mempunyai peringkat MPPA yang tinggi dibandingkan dengan rataan populasi. Hasil penghitungan MPPA dapat dilihat pada Tabel 2.

Berdasarkan Tabel 2, sapi dengan grade A, B, C dan D memiliki produksi susu perlaktasi masing-masing $6611,2 \pm 428,6(23,94 \%), \quad 5533,1 \pm 306,1 \mathrm{~kg} \quad(43,19 \%)$, $4650,4+251,5 \mathrm{~kg}(27,70 \%)$ dan $3529,5+291,3 \mathrm{~kg}(5,16 \%)$. Hasil tersebut menunjukkan bahwa ada sekitar 32,86\% sapi memiliki produksi susu dibawah standar. Tabel 2 menunjukkan bahwa antar grade memiliki perbedaan yang nyata sangat nyata $(\mathrm{P}<0,005)$. Sapi dengan grade A merupakan sapi yang bisa dijadikan indukan yang baik untuk dipertahankan, supaya bisa melahirkan keturunan yang memiliki produksi susu dengan grade A juga.

\section{Pendugaan Nilai PBV}

Dugaan nilai pemuliaan atau PBV (Probable Breding Value) merupakan salah satu cara yang dapat digunakan untuk mengevaluasi mutu genetik ternak dalam menghasilkan susu. Nilai PBV dapat dilihat pada Tabel 3.

Ternak dengan nilai pemuliaan grade A diharapkan dapat mewariskan gen kepada keturunannya, sehingga keturunannya memiliki kemampuan produksi yang baik pula. Nilai pendugaan PBV dapat digunakan untuk melakukan seleksi terhadap induk yang akan menghasilkan bibit untuk replacement stock. Umumnya ternak yang digunakan sebagai bibit adalah 10\% terbaik dari seluruh betina yang diseleksi.

Hasil penelitian menunjukkan bahwa produksi susu pada sapi perah di BPTU Baturraden mengalami kenaikan dari laktasi 1 sampai laktasi ke-4, kemudian menurun pada laktasi ke -5 , dengan masing-masing rataan produksi susu dari laktasi 1 sampai 5 berturut-turut yaitu 15,43 kg, 19,31 $\mathrm{kg}, 20,16 \mathrm{~kg}, 22,65 \mathrm{~kg}$ dan 19,45 kg (Gambar 2). Hal tersebut sesuai dengan hasil penelitian Tyler dan Ensminger (2006), bahwa sapi perah betina umumnya mencapai 
Tabel 2. Rataan MPPA Berdasarkan Grade.

\begin{tabular}{lllll}
\hline No & Grade & Jumlah Sapi(ekor) & Persentase (\%) & Rataan MPPA (Kg) \\
\hline 1 & A & 51 & 23,94 & $6611,2+428,6 \mathrm{a}$ \\
2 & B & 92 & 43,19 & $5533,1+306,1 \mathrm{~b}$ \\
3 & C & 59 & 27,7 & $4650,4+251,5 \mathrm{c}$ \\
4 & D & 11 & 5,16 & $3529,5+291,3 \mathrm{~d}$ \\
\hline
\end{tabular}

puncak produksi pada umur 6-7 tahun atau dapat dikatakan pada periode laktasi ketiga dan keempat, setelah itu terjadi penurunan produksi susu sekitar $6 \%$ setiap bulannya sampai masa afkir sapi tersebut.

Seekor ternak selalu mendapat peringkat yang sama berdasarkan nilai MPPA dan PBV. Hal ini menunjukan bahwa ternak yang mempunyai kemampuan produksi susu yang tinggi juga akan memiliki kemampuan pewarisan sifat yang tinggi. Penelitian mengenai kemampuan produksi tertaksir dan nilai pemuliaan juga dilakukan oleh Nugroho (2004) yang menyatakan bahwa ternak yang memperoleh peringkat tinggi pada perhitungan nilai pemuliaan juga akan memiliki peringkat yang tinggi pada perhitungan kemampuan produksi tertaksir.

Hasil penelitian menunjukkan, bahwa produksi susu tertinggi yang pernah dicapai pada laktasi 1 sampai dengan 5, berturut-turut yaitu $27,8 \mathrm{~kg}, 32, \mathrm{~kg}, 37,5 \mathrm{~kg}, 36,6$ $\mathrm{kg}$ dan $34,6 \mathrm{~kg}$, Dengan produksi susu tertinggi yang pernah dicapai yaitu pada laktasi ke-3 yaitu 37,5 kg (Gambar 2).

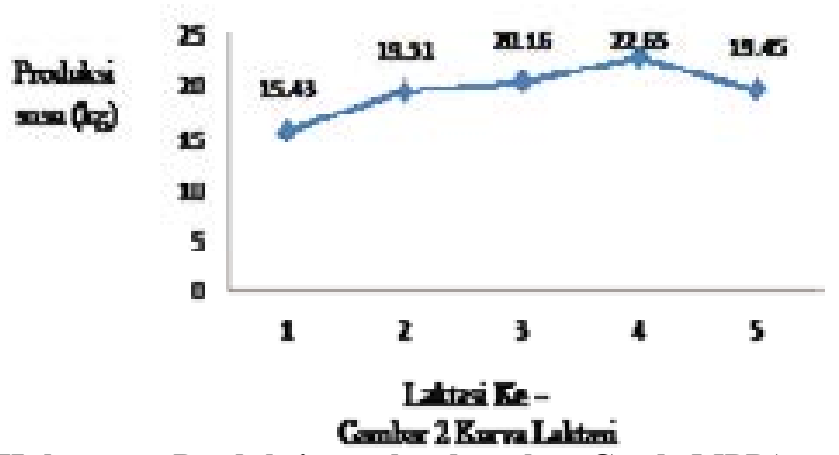

Hubungan Produksi susu berdasarkan Grade MPPA dengan Reproduksi

Produktivitas susu sapiFriesian Holstein diBBPTUSP Baturraden berdasarkan MPPA dapat digambarkan dari total produksi susu rata-rata perlaktasi selama 5 laktasi yaitu berkisar antara $3151,2 \mathrm{~kg}$ (grade D) sampai dengan rata-rata sebesar 7701,3 kg (Grade A), dengan nilai rata-rata 5443,23 $\mathrm{kg}$. Nilai rata-rata produksi susu tersebut masih pada kisaran yang baik sesuai dengan pendapat Soetarno (2003) yaitu bahwa rata-rata produksi susu dasar ME berkisar antara 4602,94 liter hingga 5888,99 liter. Data hasil penelitian performa reproduksi disajikan pada Tabel 3.

Menurut Sudrajad dan Adiarto (2011) apabila produksi susu sapi Friesian Holstein yang dipelihara di BBPTU Baturraden lebih dicermati, maka akan terlihat bahwa capaian total produksi susunya lebih rendah dari produksi susu induknya. Capaian total produksi induk tersebut berlaku sebagai gambaran mengenai potensi total produksi susu yang bisa dicapai oleh keturunannya.

Hasil penelitian menunjukkan bahwa gen FSH Sub-unit beta tidak memiliki pengaruh terhadap kemampuan produksi susu dan performa reproduksi sapi perah di BBPTU Baturraden, karena memiliki genotype yang seragam yaitu AB. Walaupun memiliki genotype yang seragam, hasil penelitian menunjukkan bahwa terdapat keragaman performa reproduksi dan produksi susu. Keragaman tersebut bisa disebabkan karena faktor lingkungan, mengingat faktor lain yaitu genetik sudah dipilih sapi Friesian Holstein unggul yang berasal dari Selandia Baru, serta pemberian pakan dan manajemen pemeliharaan sudah didasarkan pada standar yang baik. Faktor lingkungan bisa digolongkan menjadi dua yaitu faktor lingkungan dari dalam sapi itu sendiri dan faktor lingkungan dari luar seperti suhu dan kelembaban. Setiap ekor sapi akan memiliki respon yang berbeda-beda terhadap kondisi lingkungan tropis yang berbeda dengan kondisi lingkungan sebelumnya yaitu subtropis. Soetarno (2003) menjelaskan bahwa faktor lingkungan memang lebih dominan mempengaruhi produksi susu daripada faktor genetik.

Keragaman performa reproduksi dan kekampuan produksi susu sapi perah laktasi di BBPTU Baturraden dikarenakan kondisi temperatur dan kelembaban lingkungan di BBPTU-SP Baturraden belum ideal untuk pemeliharaan sapi perah laktasi, dengan kisaran temperatur lingkungan antara 22 sampai $31^{\circ} \mathrm{C}$ dengan rata-rata sebesar $25,26^{\circ} \mathrm{C}$ dan kelembaban udara antara 68 sampai $100 \%$ dengan ratarata sebesar $93,16 \%$.

Kondisi lingkungan tropis Indonesia merupakan tantangan terbesar dalam upaya optimalisasi produksi susu, karena sapi perah akan dapat berproduksi dengan baik apabila dipelihara pada kondisi lingkungan yang nyaman dengan batas maksimum dan minimum temperatur dan kelembaban lingkungan berada pada thermo neutral zone

Tabel 3. Rataan PBV Berdasarkan Grade

\begin{tabular}{llllll}
\hline No & Grade & Rataan PBV & Persentase (\%) & $\begin{array}{l}\text { PBV diatas } \\
\text { rata-rata }\end{array}$ & $\begin{array}{l}\text { PBV } \\
\text { rata-rata }\end{array}$ \\
\hline 1 & A & $6016,3+203,3 \mathrm{a}$ & 23,94 & Grade A dan B & Grade C dan D \\
2 & B & $5504,9+145,2 \mathrm{~b}$ & 43,19 & $-48 \%$ & $-52 \%$ \\
3 & C & $5086,2+119,3 \mathrm{c}$ & 27,7 & & \\
4 & D & $4554,5+138,2 \mathrm{~d}$ & 5,16 & & \\
\hline
\end{tabular}


Tabel 4. Hubungan antara Grade MPPA dengan Reproduksi

\begin{tabular}{lllccccc} 
No & \multicolumn{7}{c}{ Rataan } \\
& Grade & $\begin{array}{c}\text { Lo } \\
(\mathrm{kg})\end{array}$ & $\begin{array}{c}\text { Lama Kebuntingan } \\
\text { (hari) }\end{array}$ & $\begin{array}{c}\text { Calving } \\
\text { Interval } \\
\text { (hari) }\end{array}$ & $\begin{array}{c}\text { Kawin Pertama } \\
\text { (hari) }\end{array}$ & S/C & BCS \\
\hline 1 & A & $75,35+8,54 \mathrm{a}$ & $279,08+5,59 \mathrm{a}$ & $354,43+10,36 \mathrm{a}$ & $65,55+6,55 \mathrm{a}$ & $1,3+0,34 \mathrm{a}$ & $2,9+0,12 \mathrm{a}$ \\
2 & $\mathrm{~B}$ & $111,59+14,77 \mathrm{~b}$ & $278,76+8,10 \mathrm{a}$ & $390,35+16,82 \mathrm{~b}$ & $82,05+18,85 \mathrm{~b}$ & $1,6+0,54 \mathrm{~b}$ & $2,7+0,09 \mathrm{~b}$ \\
3 & $\mathrm{C}$ & $143,14+9,02 \mathrm{c}$ & $279,86+5,94 \mathrm{a}$ & $422,82+11,07 \mathrm{c}$ & $78,09+13,97 \mathrm{~b}$ & $2,3+0,60 \mathrm{c}$ & $2,5+0,00 \mathrm{c}$ \\
\hline
\end{tabular}

(ZTN). Menurut Rumentor (2003) diluar kondisi tersebut sapi perah akan mudah mengalami stres. Stres panas terjadi ketika temperatur dan kelembaban berada di atas ZTN. Wagner (2001) menjelaskan bahwa stres panas akan terjadi ketika panas yang masuk ke dalam tubuh ternak tidak seimbang dengan panas yang dapat dikeluarkan oleh tubuh. Menurut Rumentor (2003) parameter yang sering digunakan di berbagai negara untuk mengetahui potensi stres panas pada ternak adalah dengan Temperature Humidity Index (THI). Induk sapi perah berada pada kondisi lingkungan dengan THI kritis akan mengalami gangguan fisiologis dan produktivitas.

Secara umum saat temperatur udara rendah maka kelembaban tinggi dan sebaliknya pada saat temperatur udara meningkat maka kelembaban udara turun. Sapi perah di BBPTU Baturraden berada di lingkungan yang kurang nyaman dan berpotensi mengalami stres panas, karena temperatur lingkungan lebih tinggi dari thermo neutral zone (ZTN). Menurut Sudrajad dan Adiarto (2011) dari perbandingan antara temperatur dan kelembaban udara di BBPTU Baturraden memiliki nilai THI berkisar antara 73 sampai 82 (THI > 72). Moran (2005) menyebutkan bahwa nilai THI yang ideal bagi sapi perah adalah kurang dari 72, apabila nilai THI melebihi 72 maka sapi perah FH akan mengalami stres ringan $(72 \leq \mathrm{THI} \leq 79)$, stres sedang $(80 \leq \mathrm{THI} \leq 89)$ dan stres berat $(90 \leq \mathrm{THI} \leq 97)$. Hasil pengamatan Sudrajad dan Adiarto (2011) menunjukkan bahwa sapi Friesian Holstein di BBPTU-SP Baturraden rata-rata mengalami stres ringan.

Hasil penelitian yang dilakukan oleh Talib et al. (2002) menunjukkan bahwa di Indonesia temperatur lingkungan yang mencapai $29^{\circ} \mathrm{C}$ dapat menurunkan produksi susu menjadi $10,1 \mathrm{~kg} / \mathrm{ekor} /$ hari dari produksi susu $11,2 \mathrm{~kg} / \mathrm{ekor} / \mathrm{hari}$ jika temperatur lingkungan hanya berkisar $18-20^{\circ} \mathrm{C}$. Menurut Rumentor (2003) pengaruh langsung dari temperatur dan kelembaban terhadap produksi susu adalah disebabkan meningkatnya kebutuhan sistem tubuh untuk menghilangkan kelebihan beban panas, pengurangan laju metabolik, dan menyusutnya konsumsi pakan. Anderson et al. (1985) menyatakan bahwa penurunan produksi susu pada sapi perah yang menderita stres panas terjadi karena adanya pengurangan pertumbuhan kelenjar mammae. Bath et al. (1985) menegaskan apabila temperatur udara di atas $23.9^{\circ} \mathrm{C}$ dan kelembaban tinggi maka akan terjadi efek negatif terhadap produksi susu, baik secara kuantitas maupun kualitas.

Kondisi kelembaban lingkungan kandang terlihat sangat tinggi yaitu 68 sampai $100 \%$. Kelembaban udara yang sangat tinggi sangat mungkin terjadi karena intensitas hujan yang tinggi. Soetarno (2003) menyebutkan bahwa kelembaban ideal bagi sapi perah adalah antara 60 sampai 80\%. Gwatibaya et al. (2007) menjelaskan bahwa kelembaban udara yang tinggi dengan sedikit pergerakan udara akan menjadi salah satu faktor penyebab timbulnya stres panas pada sapi perah.

Hasil pengamatan Sudrajad dan Adiarto (2011) terhadap status fisiologis sapi perah di BBPTU Baturraden menunjukkan bahwa frekuensi respirasi lebih tinggi dari normal berkisar antara 25,33 hingga 80,00 kali/menit dengan rata-rata 50,71 kali/menit, frekuensi pulsus masih dalam keadaan normal antara 46,00 hingga 84,00 kali/menit dengan rata-rata $62,84 \mathrm{kali} /$ menit, dan temperatur rektal juga masih berada pada keadaan normal antara 35,63 hingga $39,13^{\circ} \mathrm{C}$ dengan rata-rata $37,63^{\circ} \mathrm{C}$.

Frekuensi respirasi sapi perah di BBPTU Baturraden terlihat lebih tinggi dari kisaran normal, karena menurut Frandson (1996) frekuensi respirasi normal sapi perah berkisar antara 24 sampai $32 \mathrm{kali} /$ menit. Tingginya frekuensi respirasi ini akibat perubahan kondisi temperatur dan kelembaban, Rumetor (2003) menjelaskan bahwa naiknya frekuensi respirasi merupakan salah satu tanda sapi perah mengalami stres panas. Tujuan dari repirasi ini adalah untuk memaksimalkan pengeluaran panas karena sapi perah berada di kandang dengan kelembaban tinggi.

\section{Hubungan antara BCS dengan MPPA}

Body condition score (BCS) merupakan suatu metode penilaian secara subyektif melalui tehnik penglihatan (inspeksi) dan perabaan (palpasi) untuk menduga cadangan lemak tubuh terutama untuk sapi perah pada periode laktasi dan kering (Edmonson et al 1989). Penilaian BCS telah diterima sebagai metode yang murah dalam pendugaan lemak tubuh yang digunakan baik pada peternakan komersial maupun penelitian (Otto et al. 1991). Pada penelitian ini penilaian BCS menggunakan skala $1-5$ ( $1=$ sangat kurus, $3=$ sedang, dan $5=$ sangat gemuk) dengan nilai 0,25 angka diantara selang itu.

Body condition score (BCS) juga dijadikan sebagai alat untuk menjelaskan status nutrisi ternak melalui evaluasi dari cadangan lemak dari hasil metabolisme, pertumbuhan, laktasi, dan aktivitas (Wright et al. 1987). Sapi laktasi mengalami penurunan cadangan lemak tubuh selama awal laktasi, kemudian disimpan kembali pada saat pertengahan dan akhir laktasi (Gallo et al. 1996).

Nilai BCS berkorelasi positif dengan produksi susu, menutut Coffey et al.(2003) perubahan keseimbangan 
energi yang terjadi selama laktasi akan berpengaruh terhadap BCS. Domeq et al. (1997) menyatakan bahwa setelah sapi beranak, sapi perah akan mengalami peningkatan konsumsi pakan yang lambat, peningkatan produksi susu yang cepat, dan terjadi peningkatan mobilisasi cadangan lemak tubuh untuk memenuhi kekurangan konsumsi pakan akibat peningkatan kebutuhan produksi susu pada awal laktasi. Data hasil penelitian tentang hubungan antara MPPA dengan BCS dapat dilihat pada Tabel 5.

Hasil penelitian menunjukkan bawah nilai BCS berbeda nyata pada sapi yang memiliki produksi susu grade $\mathrm{A}, \mathrm{B}$ dan $\mathrm{C}$, dengan nilai BCS pada masing-masing grade yaitu $3,1 \pm 0,22,2,8 \pm 0,15$ dan $2,7 \pm 0,22$. Semakin bagus grade produksi susu, nilai BCS semakin tinggi. Nilai rataan BCS perlaktasi pada grade A menunjukkan BCS yang ideal yaitu 3,1 $\pm 0,22$, sesuai dengan rekomendasi Penstate (2004), bahwa nilai BCS yang ideal untuk sapi perah laktasi yaitu pada awal melahirkan $(3,5)$, awal laktasi $(3,00)$, puncak produksi susu $(2,75)$, pertengahan laktasi $(3,00)$ dan akhir laktasi $(3,25)$ dengan nilai rataan BCS 3,1. Sedangkan sapi dengan grade $\mathrm{B}$ dan $\mathrm{C}$ memiliki BCS dibawah rekomendasi. Hal ini menunjukkan bahwa sapi dengan grade A memiliki keseimbangan energi antara pakan yang diberikan dengan kebutuhan fisiologis tubuhnya. Pakan yang diberikan di BBPTU Baturraden merupakan pakan yang memiliki kualitas baik, tetapi dengan kondisi pakan yang sama menghasilkan nilai BCS yang berbeda untuk masing-masing grade.

Nilai BCS pada grade B dan C masih di bawah nilai yang direkomendasikan. Rendahnya nilai tersebut, dikarenakan kurang baiknya kondisi fisiologis sapi pada grade $\mathrm{B}$ dan $\mathrm{C}$ jika dibandingkan dengan sapi pada grade $\mathrm{A}$. Kondisi fisiologis yang kurang baik bisa diakibatkan oleh faktor lingkungan, diantaranya bisa karena heat stress akibat THI yang terlalu tinggi.

Body Condition Score (BCS) menggambarkan sejumlah energi metabolik yang tersimpan sebagai lemak subcutan dan otot pada ternak (Montiel dan Ahuja, 2005). Energi yang tersedia dalam tubuh tersebut digunakan untuk metabolisme, pertumbuhan, laktasi dan aktivitas (Wright et al., 1987). Lemak tubuh akan digunakan lebih banyak sebagai cadangan energi pada saat laktasi untuk produksi susu. Data menunjukkan bahwa sapi di BBPTU Baturraden pada umumnya akan mengalami stress ringan karena memiliki THI 73 sampai 82 (THI > 72). Kondisi stress ringan ini akan menyebabkan adanya gangguan secara fisiologis, sehingga cadangan lemak selain digunakan untuk produksi susu, metabolisme, pertumbuhan dan aktivitas, juga digunakan untuk menanggulangi stress. Kondisi inilah yang mennyebabkan rendahnya nilai BCS pada sapi grade $\mathrm{B}$ dan $\mathrm{C}$.

Hasil analisis korelasi menunjukkan bahwa terdapat hubungan yang erat antara BCS dengan produksi susu yaitu

Tabel 5. Hubungan MPPA dengan BCS

\begin{tabular}{llll}
\hline No & MPPA & Grade & Rataan BCS \\
\hline 1 & $6611,2+428,6 \mathrm{a}$ & A & $3,1+0,22 \mathrm{a}$ \\
2 & $5533,1+306,1 \mathrm{~b}$ & B & $2,8+0,15 \mathrm{~b}$ \\
3 & $4650,4+251,5 \mathrm{c}$ & C & $2,7+0,22 \mathrm{c}$ \\
\hline
\end{tabular}

dengan nilai $\mathrm{r}=0,68$. Hubungan antara $\mathrm{BCS}$ dengan produksi susu dinyatakan dalam persamaan regresi MPPA $(\mathrm{Kg})=-$ $59+1991$ BCS, artinya dengan kenaikan BCS satu satuan akan meningkatkan produksi susu $1991 \mathrm{~kg} /$ laktasi. Dengan demikian BCS memiliki pengaruh yang yang cukup besar terhadap produksi susu.

\section{KESIMPULAN}

Sapi FH di BPTU mempunyai nilai repitabilitas 0,84, sedangkan nilai heritabilitas 0,4 . Nilai MPPA sapi dengan grade $\mathrm{A}, \mathrm{B}, \mathrm{C}$ dan $\mathrm{D}$ memiliki produksi susu perlaktasi masing-masing $6611,2 \pm 428,6(23,94 \%), 5533,1 \pm 306,1 \mathrm{~kg}$ $(43,19 \%), 4650,4 \pm 251,5 \mathrm{~kg}(27,70 \%)$ dan $3529,5 \pm 291,3 \mathrm{~kg}$ $(5,16 \%)$. Gen FSH Sub-unit beta tidak memiliki pengaruh terhadap kemampuan produksi susu dan performa reproduksi, karena memiliki genotype yang seragam yaitu AB. Nilai BCS memiliki pengaruh yang yang cukup besar terhadap produksi susu yaitu dengan nilai $r=0,68$. Hubungan antara BCS dengan produksi susu dinyatakan dalam persamaan regresi MPPA $(\mathrm{Kg})=-59+1991 \mathrm{BCS}$, artinya dengan kenaikan BCS satu satuan akan meningkatkan produksi susu $1991 \mathrm{~kg} /$ laktasi.

\section{DAFTAR PUSTAKA}

Anderson RR, Collier RJ, Guidry AJ, Heald CW, Jenness R, Larson BL \& Tucker HA. 1985. Lactation. The Iowa University Press, Ames, Iowa.

Andreas E, Sumantri C, Farajalah A \& Anggraeni A. 2010. Identification of GH|Alul and GHR|Alul genes polymorphism in Indonesian Buffalo. J. Indonesian Trop Anim Agri 35: 215 - 221.

Bath DL, Dickerson FN, Tucker HA \& Appleman RD. 1985. Dairy Cattle: Principles, Practices, Problems, Profits. Lea and Febigr. Philadelphia.

Becker WA. 1975. Manual of Quantitative Genetiks. $4^{\text {th }}$ Edition. Published by Academic Enterprise. Pullman, Washington: 37-42.

Coffey MP, Simm G, Hill WG \& Brotherstone S. 2003. Genetic Evaluation of Dairy Building for Daughter Energy Balance Profil using Linier Types Scores and Body Condition Score Analyzed using Random Regressions. J. Dairy Science 86: 2205 - 2212.

Dai L, Zhihui Z, Zhao R, Xia S, Hao Jiang, Xupeng Yue, Xichun Li, Yan Gao, Liu J \& Zhang J. 2009. Effects of novel single nucleotide polymorphisms of the FSH beta-subunit gene on semen quality and fertility in bulls. J Anim.Reprod. Sci. 114 : 14-22.

Direktorat Budidaya Ternak. 2012. Pedoman Teknis Pengembangan Budidaya Sapi Perah Pola PMUK. Direktorat Jenderal Peternakan dan Kesehatan Hewan, Jakarta.

Direktorat Jenderal Peternakan dan Kesehatan Hewan. 2012. Statistik Peternakan. Kementrian Pertanian Republik Indonesia, Jakarta.

Domeq JJ, Skidmore AL, Lloid JW \& Kaneene JB. 1997. Relationship between body condition score and milk yield in a large dairy herd of heigh yielding Holstein 
cows. J. Dairy Sci. 80: $101-112$.

Edmonson AJ, Lean IJ, Weaver LD, Farver T \& Webster G. 1989. A body condition scoring chart for Holstein dairy cows. J. Dairy Sci. 72: $68-70$.

Falconer DS \& Mackay TFC. 1996. Introduction to Quantitative Genetics. Longman Inc, New York.

Frandson RD. 1996. Anatomi dan Fisiologi Ternak. Gadjah Mada University Press, Yogyakarta.

Gallo L, Carnier P, Cassandro M, Mantovani R, Bailoni L \& Bittante G. 1996. Change in body condition score of Holstein cows as affected by parity and mature equivalent milk yield. J. Dairy Sci. 79:1009 - 1015.

Gwatibaya, S, Svotwa E \& Jambwa D. 2007. Potential Effects and Management Options for Heat Stress in Dairy Cows in Zimbabwe: A Review. EJEAFChe 6(5): $2066-2074$.

Hidayat A, Effendi P \& Sugiwaka T. 2002. Informasi Teknologi Penunjang pada Kesehatan Reproduksi. Buku petunujuk Teknologi Sapi Perah di Indonesia untuk Petugas penyuluh dan Petugas Teknik. Cetakan Pertama. PT. Sonysugema Pressindo, Bandung.

Ishak ABL, Sumantri C, Noor RR \& Arifiantini I. 2012. Identification of polymorphism of FSH beta-subunit gene as sperm quality marker in Bali cattle using PCRRFLP. J.Indonesian Trop.Anim.Agric. 36(4): 221-227.

Liu JJ, Ran XQ, Li S, Feng Y \& Wang JF. 2009. Polymorphism in the first intron of follicle stimulating hormone beta gene in three Chinese pig breeds and two European pig breeds. J Anim Reprod Sci 111 : 369-375.

Montiel F \& Ahuja C. 2005. Body condition score and suckling as factor influencing the duration of postpartum anestrus in cattle: A review. Anim. Rep. Sci. 85:1-26.

Moran J. 2005. Tropical Dairy Farming : Feeding management for small holder dairy farmers in the humid tropics 321 pp., Landlinks Press.

Noor RR. 2010. Genetika Ternak. Penebar Swadaya, Jakarta.

Nugroho CW. 2004. Pendugaan nilai pemuliaan dan genetic trend produksi susu di peternakan sapi perah Taurus Dairy Farm, Cicurug-Sukabumi. Tesis. Program Pascasarjana. Institut Pertanian Bogor, Bogor.

Otto RL, Ferguson JD, Fox DG, Sniffen CJ. 1991. Relationship between body condition score and compotition of ninth to eleven rib tissue in Holstein dairy cows. J Dairy Sci. 74:852-861.
Pallawaruka. 1999. Ilmu Pemuliaan Ternak Perah. Ilmu Produksi Ternak. Fakultas Peternakan. Institut Pertanian Bogor, Bogor.

Penstate. 2004. Begginer's guide to body condition scoring: A tool for dairy herd management. Web presentation.

Rumetor SD. 2003. Stres panas pada sapi perah laktasi. Makalah Falsafah Sains. Program Pascasarjana Institut Pertanian Bogor, Bogor.

Sambrook J, Fritsch EF \& Maniatis T. 1989. Molecular Cloning. A Laboratory Manual $2^{\text {nd }}$ ed. Cold Spring Harbor Laboratory Press, USA: 9.16 - 9.19.

Soetarno T. 2003. Manajemen Budidaya Sapi Perah. Fakultas Peternakan, Universitas Gadjah Mada, Yogyakarta.

Sudrajad P \& Adiarto. 2011. Pengaruh stres panas terhadap performa produksi susu sapi Friesian Holstein di Balai Besar Pembibitan Ternak Unggul Sapi Perah Baturraden. Seminar Nasional Teknologi Peternakan dan Veteriner.

Talib C. 2002. Sapi Bali di daerah sumber bibit dan peluang pengembangannya. Wartazoa $12: 3-6$.

Tyler HD \& Ensminger ME. 2006. Dairy Cattle Science. $4^{\text {th }}$ Edition. Prantice Hall, New Jersey.

Warwick EJ \& Legates JE. 1979. Breeding \& Improvement of Farm Animal. Tata McGraw-Hill Publishing Company, LTD., New Delhi.

Warwick EJ. 1983. Pemuliaan Ternak. Terjemahan J.M. Astuti \& W. Hardjosubroto. Gadjah Mada University Press, Yoyakarta.

Wright IA, Rhind SM, Russel AJF, Whyte TK, Mcbean AJ \& Mcmillen SR. 1987. Effects of body condition, food intake and temporary calf separation on the duration of the post-partum anoestrus period and associated LH, FSH and prolactin concentration in beef cows. Anim. Prod. 45: 395-402.

Xiaopeng AN, Dan H, Jin-Xin H, Guang L, Ya-Na W, Ling L, Guang Q, Jiangang W, Yu-xuan S \& Binyun CY. 2010. Polymorphism of exon 2 of $\beta$ gene and its relationship with reproduction performance in two goat breeds. Agric. Sci.China. 6:889-886. 